Original Paper UDC 165.6:[27-14+141.144]Veber, F.

doi: $10.21464 / \mathrm{sp} 31105$

Received December $14^{\text {th }}, 2014$

\author{
Bojan Žalec \\ University of Ljubljana, Faculty of Theology, Poljanska cesta 4, SI-1000 Ljubljana \\ bojan.zalec@guest.arnes.si
}

\title{
On Why Semantic Externalism, Creationist Theism, Personalism, and Veber's Philosophy Fit Together Very Well
}

\begin{abstract}
The main theses of this paper are that semantic externalism (SE) and creationist theism (CT) are compatible, and that SE and personalism are mutually inclined. This view can be fruitfully illustrated and enriched by the use of the philosophy of France Veber (1890-1975), who was Meinong's pupil. He argued that there is a special side of our experience which he called "hitting upon reality" and which is fundamentally different from the presentation of phenomena. The author points to some parallels of the distinction between hitting upon reality and presentation on one hand and Putnam's view on reference and representation on the other. The most important constituents of the frame of reference of this paper are the works of philosophers Robert Howell, Hilary Putnam, Tyler Burge, and France Veber. The main original contribution of this paper represents the finding that SE and personalism are mutually inclined.
\end{abstract}

\section{Keywords}

semantic externalism, creationist theism, personalism, hitting upon reality, Robert Howell, France Veber

\section{Introduction}

The main theses of the present essay are:

1. Semantic externalism (SE) and creationist theism (CT) are compatible;

2. SE and personalism are mutually inclined.

This view can be fruitfully illustrated and enriched by the use of the philosophy of France Veber (also Franz Weber, 1890-1975). Veber was Meinong's pupil, and later a professor of philosophy at the University of Ljubljana. His (later) philosophy can be characterized as Christian personalism. Veber argued that there is a special side of our experience which he called "hitting upon reality" and which is fundamentally different from the presentation of phenomena (cf. Veber 1939). According to Veber, hitting upon reality was neglected by phenomenology (with the term 'phenomenology' Veber referred to the philosophy of Meinong and Husserl). I will point to some parallels of the distinction between hitting upon reality and presentation on one hand and Putnam's view on reference and representation on the other.

The most important constituents of the frame of reference of this paper are the works of philosophers Robert Howell, Hilary Putnam, Tyler Burge, and France Veber. The philosophical method which I use consists of linguistic and conceptual analysis as well as thought experiments. The main scientific 
contribution of this article represents the finding that SE and personalism are mutually inclined.

The crucial factor which triggered me to work on the subject of this paper was the appearance of Robert Howell's article on CT and SE (2011). I accept both CT and SE, and thus Howell's thesis of the incompatibility of SE and CT has represented a challenge for me. This essay is my reply to this challenge. In the first part of the paper I outline the main elements of semantic externalism (Putnam, Burge) and its implications. In the second part I present Howell's argument for the incompatibility of CT and SE. In the third part I present the Veberian variant of semantic externalism, which can be formulated on the basis of Veber's philosophy. In the fourth part I deal with personalism in the context of Veber's thesis that some persons are inherently bad, vicious, and with semantic externalism. In the "Conclusion" I establish some relations between semantic externalism, creationist theism, and personalism.

\section{What is SE?}

Hilary Putnam argued for the thesis that reference cannot be explained by intrinsic characteristics of representations (he opposed the so-called magical theories of reference). ${ }^{1}$ In this framework he presented - in his now already classical essay "The Meaning of 'Meaning"' (1975) - a famous thought experiment about Twin Earth and presented the theses and concepts of his semantic externalism: intension (stereotype), extension (meaning, reference), the division of linguistic labour, the indexicality of most terms, the causal relations needed for reference etc. According to Putnam, the error of the traditional philosophy of language is that it took into consideration neither the contribution of others (division of the linguistic labour), nor the contribution of the world (indexicality of most terms). A better philosophy and a better science about language must take into account both (Putnam 1975, 271). Putnam's work was importantly supplemented by Tyler Burge (cf. Burge 1979; 1986; 1989; 2007), Fred Dretske (1995), and some other philosophers.

The main claims of semantic externalism are:

1. Meanings are not in the head;

2. We cannot individuate the meanings without taking into consideration some aspects of the environment of the person (organism);

3. Intension does not determine the reference. ${ }^{2}$

\section{1. 'Internalism' and 'externalism' are homonyms}

It is also useful to mention the fact that the word 'externalism' is a homonym, a term used in different senses. Thus, for instance, we must distinguish between epistemological externalism/internalism and semantic externalism/ internalism. In this paper I deal only with the second one. We must also distinguish between social externalism and semantic externalism, like Cristina Lafont (2005) does. Lafont proves that Heidegger was a social externalist, but nevertheless a semantic internalist. Social externalism tries to give an answer to the question "Whose concepts are correctly (properly) individuated?", and semantic externalism tries to give an answer to the question "What do we need for correct (proper) individuation of concepts?". Lafont thinks that Heidegger's social externalism comes out from his intersubjective concep- 
tion of language, whereas his concept of ontological difference bounds him to semantic externalism (ibid.). Thus we can see that it is not possible, on the basis of one type of externalism, to ascribe to one philosopher another type of it; as it is not true that one type of externalism comes out of another type of it. We could say that semantic externalism is a type of broader explaining or interpretational externalism with the following basic question: "What is necessary to explain a certain thing, a certain x?" An explanatory or interpretational externalist answers that for an explanation or interpretation we must take into account the elements of person's or organism's environment, and the explanatory or interpretational internalist denies that. So for example Fred Dretske (1995) argues that certain natural phenomena cannot be explained in an internalist way. Jerry Fodor, who defines psychology as a science about behaviour (its task is to explain behaviour), argued for the thesis that causal powers, which must be taken into account when we are explaining behaviour, are internalistically specifiable. By those who think that semantic characteristics are also explanatory relevant, the position about semantic externalism/ internalism coincides with the position about explanatory/interpretational externalism/internalism.

It seems that naturalism (ontological or methodological) does not imply semantic internalism or externalism. For example, Fodor is a naturalist and also an internalist at the same time; Dretske is a naturalist as well, yet he is an externalist. Philosophers involved in the discussion about externalism (anti-individualism) versus internalism (individualism) are (mostly), at least in some respect, all naturalists or at least they naturalistically limit the area of their discussion. That is maybe also the reason for the fact that it took (more than) twenty years for somebody (Howell) to realise the importance of semantic externalism for philosophical theology since many philosophical theologians are anti-naturalistically oriented, and for that reason they (alas) do not know the important works and discussions of naturalistic philosophers at all (they are simply not interested in them) or they do not understand them very well.

I should add to what I said above that much of the discussion between internalists and externalists is of principal nature, that they discuss about what is in principle necessary, logically needed for individuation or explanation or interpretation. Neither of them denies the causal relations between a person/ organism and her/his environment.

Therefore, a non-differentiated or not sufficiently specified ascribing of some kind of externalism/internalism to some particular philosopher is not very enlightening and could even be misleading. Thus, for instance, the fact that one ascribes semantic externalism to some philosopher (or confuses different kinds of externalism/internalism) solely on the basis of the virtue of certain "externalist" facts ${ }^{3}$ is rather damaging for a philosophical debate

Cf. Putnam 1975; 1991b; 1991c; 1992. 2

Among the critics of semantic and methodological externalism it is useful to mention Jerry Fodor (1991a; 1991b; 1994). (Putnam-Burge version of) SE was also rejected by Donald Davidson (1990). I addressed both criticisms in Žalec 1999.
3

For example that particular account sensation, direct contact with reality, outer observation or area intentionality plays an important role, or that outer reality is important for the survival of a person/organism, and so on. 
on quality. The above mentioned example of Heidegger nicely illustrates my point. ${ }^{4}$

\section{The meaning of SE}

The claims of SE have important philosophical implications or effects. Let me mention only two of them. SE is the basis of one of the most important anti-sceptic arguments in the modern philosophy which is based on the brainin-a-vat thought experiment which was presented by Putnam in the article with the same title. On the basis of SE, Putnam inferred a justified conclusion that brain in a vat is not possible. Recently, the American philosopher Robert Howell (2011) presented arguments for the thesis that SE is incompatible with the creationist theism.

\subsection{Brain in a vat}

The essence of Putnam's argument from his article "Brains in a Vat" is maybe most easily explained with the comparison of the following two statements: "I am a brain in a vat" and "I do not exist". Putnam argues: If I do not exist then the statement "I do not exist" is false. So "I do not exist" is necessarily wrong if it is true that I do not exist. Similarly, it holds true for the statement "I am a brain in a vat". If I am a brain in a vat, then the statement "I am a brain in a vat" is false. Consequently, the statement "I am a brain in a vat" is necessarily false, if I am a brain in a vat. The statement "I am a brain in a vat" is a counterfactual situation. If I were a brain in a vat, the statement is false if SE is true because it claims that we are only a brain in a vat in brain's "picture", and not a real brain in a vat. In short, it says that we are something else than a real brain in a vat (and consequently it is false). This is Putnam's argument for the thesis that a hypothesis "we are a brain in a vat" is self-defeating. Formally speaking, we can say that for the statement "I am brain in a vat" the following holds true (the same as for the statement "I do not exist"):

If $p$, then ' $p$ ' is necessarily false.

Putnam pointed out that regardless of whether a brain in a vat is physically possible, it is not really possible. This possibility is eliminated by philosophy, not physics (Putnam 1975, 15).

\subsection{Putnam's internal realism ${ }^{5}$}

Putnam thinks that the hypothesis that I do not exist is self-defeating. Here he agrees with Descartes. Self therefore exists. Afterwards he proves that the hypothesis "we are a brain in a vat" is self-defeating, that outer world exists (we are in causal relations with it). But the world which is the object of my thought and of my speech may be pretty different from what I think. I grasp the world, and parts of the world with which I am in a causal and reference relation, only through my concepts (intensions or stereotypes); but the real world or its structure may be different from my grasping of it and it has layers and structures which are unknown to me. I cannot grasp the world in any other way but only through my intensions or stereotypes. This is Putnam's inner realism. It is inner because I cannot grasp the world differently, but only through my stereotypes and intensions, and realism because the object of my thinking is nevertheless the real world with which I am in a causal relation. 
This is really a variant of Kant's philosophy. Kant: there must exist a world on its own, a thing in itself. What would otherwise affect my senses? Yet only the world of phenomena is accessible to me. Putnam: there exists a real and objective world (world on its own) which has causal effects on me, but I can grasp it only through my stereotypes. Further we can say that by Putnam's distinction between reference and stereotypes in a way Frege's distinction between sense (Sinn) and reference (Bedeutung) is preserved: references are referents of my thought (things with which we are in a causal relation), and senses are stereotypes through which we experience or grasp those referents.

\subsection{Burge's contribution}

Let us now turn our attention to Burge's variant of externalism. Tyler Burge, in a series of articles, presented several thought experiments in favour of the externalist (or, as he called it, anti-individualistic) position. He argued for two claims:

1. The representational natures of mental states of persons/organisms can be different despite the identity of the individualistic descriptions of persons/ organisms;

2. Representational (i.e. intentional) properties (the properties of mental states depending on which aspects of the outer world they represent) are causal powers relevant for the explanation of behaviour.

Burge's thought experiments are of two kinds. The first supposed to show that the representational features of mental states depend on the mental or social environment of their subject. The experiments of the second kind suggest that the representational properties of mental states depend on the non-mental environment of their bearer. Besides, it is useful to mention that individualists claim that all mental states can be properly individuated - regarding their representational properties, and for the needs of the explanation of behaviour - independently of the aspects of the environment of the subject of mental states. Thus, strictly taken, one counterexample is enough for the externalist account to falsify the internalist (individualist) account.

Let me now briefly outline maybe the most famous of Burge's thought experiments, which he presented in favour of SE in his essay "Individualism and the Mental". Let us imagine Peter ${ }_{1}$ who lives in Dublin and who has arthritis. Peter $_{1}$ has a lot of true beliefs about arthritis (for instance, that he has arthritis

We can observe such an assigning of externalism to Veber, which is not as differentiated as it should be, in an article of Matjaž Potrč (1989), who otherwise in detail and extensively dealt with the topic of (semantic) externalism. From his article we can understand that the author uses the term 'externalism' in order to refer to a kind of general claiming or emphasizing the meaning of person's/ organism's environment. But I would like to emphasize once more that such importance of environment can also be accepted by a semantic internalist. Therefore, such understanding of externalism/internalism is in a sense trivial. A characteristic of good philosophy is taking into consideration (and with great philosophers also introducing) a set of relevant distinctions which others do not consider, do not know, and therefore their thinking is in a certain sense, in comparison to the philosophical one, inferior or not relevant. Potrč in the mentioned article defended the statement that internalism and externalism could serve as a criterion for the periodization of Veber's philosophy. This Potrč's idea about the periodization of Veber's philosophy can be more than twenty years later traced in an article of Pihlar (2012) who has also taken over Potrč's (insufficiently specified) concept of externalism.

Cf. Putnam 1987, also 1991d. 
for many years, that he has arthritis on joints etc.) But one day Peter ${ }_{1}$ started to feel a pain in his thigh. Peter ${ }_{1}$, who is intelligent, rational and who speaks English well, visits a doctor. He says to the doctor that he feels a pain in his thigh that is very similar to the pain in his joints and that he is afraid that arthritis has spread to his thigh. The doctor answers that this is not possible because arthritis is an inflammation which only affects joints. The doctor adds that every dictionary will tell him the same. Peter ${ }_{1}$ changes his mind and asks the doctor what else could be the cause of the pains in his thigh.

Let us imagine now some other (counterfactual) community in which Peter lives. Peter ${ }_{2}$ is a molecular copy of Peter ${ }_{1}$. Peter ${ }_{1}$ and Peter ${ }_{2}$ are totally identical if we describe them non-intentionally. Peter ${ }_{1}$ and Peter $_{2}$ are in totally identical phenomenal (introspective) states. Peter ${ }_{1}$ and Peter ${ }_{2}$ have totally identical non-intentionally specified history. The difference between the first and the second situation is only in communities in which both patients live. In the first community (of Peter ${ }_{1}$ ) the standard use of 'arthritis' (the use prescribed by dictionaries) is only for inflammations of joints. In the second community (of Peter ${ }_{2}$ ) the standard use of 'arthritis' is like Peter ${ }_{1}$ (incorrectly) used it i.e. for every rheumatic inflammation. The mental states of both Peters are specified with the content sentences which include the word 'arthritis'. The content sentences - which include expressions with different extensions - specify different mental states.

Burge's conclusion is that Peter ${ }_{1}$ and Peter $_{2}$ are in identical individualistically specified states and yet they are in different intentional (i.e. representational) states. Yet there are three assumptions that make the construction of his thought experiment possible. The first assumption is that the content of mental state is ascribed by filling the empty place in the content sentence (for instance "Peter ${ }_{1}$ thinks that ...") by the sentence which would be uttered by the bearer of the mental state himself (in case of our example Peter ${ }_{1}$ ) in the moment of ascribing if he were sincere, and conscious of his utterances. If we ascribe the content to the people who speak a different language we fill the empty space with the literal translation of a sentence uttered by the speaker himself in the moment of ascribing if he were sincere, conscious of his utterances etc. Burge's argument has a very broad application. It does not depend on what kind of a word 'arthritis' is. It can be used for concrete kinds, for abstract objects, in short for all objects if only the above listed assumptions are true. The second assumption is that we ascribe the terms which appear in the sentences which specify the content of the mental states of the speaker a standard meaning, i.e. the meaning determined by the conventions and norms (dictionary meaning) of the community in which the subject of the mental states lives. The third assumption includes the possibility of false or incomplete understanding of some concept and false use of the corresponding term (use which is not in accordance with the standards of the linguistic community of the speaker), and the possibility of the counterfactual situation (world) in which this (incorrect) use is standard, and in which the internalist twin of the speaker from the actual situation (world) lives.

In essence, Burge's thought experiments presuppose Putnam's findings, but he supplemented or enriched Putnam's achievement by two things: he contributed different examples (thought experiments) in which we can better understand the implications of Putnam's discovery, and he essentially spread the scope of externalism by showing that it is also true for mental states that do not depend on language. Such mental states are the intentional states of animals and also some mental states of people. Such states are, for instance, 
states from the early phase of visual perception. At that point Burge lent on the theory of visual perception developed by David Marr (cf. Marr 1982).

"Early human vision makes use of a limited range of representations - representations of shape, texture, depth and other spatial relations, motion, color, and so forth. These representations (percepts) are formed by processes that are relatively immune to correction from other sources of information; and the representations of early vision appear to be fully independent of language." (Burge 2007, 238)

Alas, there is no place for presenting this second kind of thought experiment, but this is not so crucial regarding our present essay because the main subject of it is the compatibility of CT and SE, and my aim here is not to examine at length whether SE is true or not. Still, it is somehow fair to add that I do think that SE is true (otherwise I would not be motivated to scrutinize the compatibility of $\mathrm{CT}$ and SE). To conclude: I think that the representational properties of mental states are dependent not only on some aspects of mental environment, but also on some aspects of the non-mental environment of their bearer. In short, I think that SE is true. Secondly, I also think that there is a lot of truth in CT. In this essay I want to check whether my view is justified by examining whether SE and CT are compatible or not. So let us turn back to this main line of the present essay and ask: are Putnam's and Burge's version of SE compatible with the Christian idea of a God Creator?

\section{SE and the omniscience of God}

I think that Putnam's externalism about the reference of terms is compatible with the Christian traditional idea of God who created the world with his intention. God is omniscient so God's descriptions or intensions always correspond with the thing to which God refers. God knows all (secret) structures. The structures of things to which the human speaker (indexically) refers play an important role in Putnam's examples by which he supports his claims. What about Burge's individuation externalism: is it compatible with the Christian idea of a God Creator?

The following line of thought is possible: Before God created the world, there had been no environment, so his thought could not have been dependent on the world, because there had been no world. But the moment God created the world the problem ceased to exist because the world exists and Burge's externalism holds true for God.

Furthermore, God creates the world performatively: He uttered 'light' and there was the light. God's word 'light' refers to light which He created with the performative act 'light'. For God there are no secret structures, as already mentioned, so His intension completely corresponds to the thing to which $\mathrm{He}$ refers with the word 'light'. God had an image of light. But this image covers all the knowledge about light which He created. There can be nothing in God's environment that is not already in God's mind. And God is the only such being. There can be nothing in God's environment that is not already in God's mind, and at the same time God is aware of everything what is in His mind and also aware that He is aware of that. And only for God it holds true that $\mathrm{He}$ is such a being that there can be nothing outside His mind what is not already in His mind. So God is the only being for whom it is impossible that $\mathrm{He}$ is in identical narrower states, and in different broader (semantic) states. An identical narrow states/different broader states situation is possible only in beings who do not have absolute knowledge about the things they refer to. So 
it is possible that a human being does not know that the chemical structure of the liquid $\mathrm{He}$ refers to as water is $\mathrm{H}_{2} \mathrm{O}$.

\subsection{Howell's position and the arguments against it}

Howell presents creationist theism (CT) as a position claiming the following: God imagined the world first, and only afterwards He created it in accordance with that image. Howell further accepts the premise that according to SE a thought is logically (not only accidentally or contingently) dependent on its environment or object. On this basis he presents his argument about the incompatibility of CT and SE: Before the world existed, God could not have had referred to the world, because it had not existed. So He could not have had a thought about it. Therefore, $\mathrm{CT}$ is false. Howell anticipates some arguments against his position.

\subsubsection{God's mind is radically different from the human mind; SE holds true for the human mind, but not for the mind of the almighty God (Howell 2011, 176)}

By this objection we should take into consideration the thoughts about the implications of Howell's argument which Howell presented at the end of his paper. He points out that, if we accept CT, then SE does not hold true for some minds and loses some of its generality. This would maybe not seem so pernicious to some. But concern arises from the fact that the methodology which leads us to accept SE is not very empirical. It is based on thought experiments, reflection, and concept analysis (Howell 2011, 179). If we agree that the evidence from SE is of a priori nature, and I think that it is, then saying that God's mind is radically different from the human one (in order to avoid the incompatibility of CT and $\mathrm{SE}$ ) is not a very convincing option. Our concept of the personal God is very closely connected with our concept of our mind, the mind of persons. If we exaggerate with emphasizing the difference between our and God's mind, between mind and the Mind, then we risk that the claim that we and God are persons, or if you like it, that we are God's image, becomes unconvincing and without a comprehensible basis. The significance of abandoning the thesis that God is a person as we are (respectively that human being is imago Dei) for the Christian and Jewish religion is beyond question. Or with the words of Howell himself:

\footnotetext{
"No doubt this will not bother entrenched philosophical theologians, but like all philosophers, such theorists ought to take care not to abandon the spirit in defense of the doctrine (ibid.)."
}

We will latter supplement our reply to this objection.

\subsubsection{God is not temporal}

Howell's answer: OK, let us give up the temporal meaning of the term 'before', and let us accept the ontological meaning of 'before' so that God's thought about the world is dependent on the world (regardless of the temporal aspect of the relation between God's thought and the world) (Howell 2011, 178). But this is also incompatible with CT.

\subsubsection{CT as such does not imply creatio ex nihilo; Howell's argument concerns CT only if it implies creatio ex nihilo}

Before presenting Howell's answer, first a brief remark. Despite the fact that on the one hand creatio ex nihilo is metaphysically suspect, it is on the other hand an important part of the traditional concept of God. But this is not the 
crucial point, it is only a remark. As an answer, the following is what is really important: This argument can be used in a wider sense because it also concerns the position which does not claim that God created the world ex nihilo, but it claims that he created it from a substance which is not in the relation of a deductible composition of the world, therefore from a completely different substance, let us call it stuff. In short, this argument does not concern only the position which literally and absolutely accepts creatio ex nihilo (God created literally everything, there is nothing outside God what he did not create), but also the positions which claim that God created the world from stuff. Howell argues that the argument does not show only the incompatibility of SE and the God who created the world out of nothing, but also of the God who created the world out of stuff. And this Howell's claim is, in my opinion, false. This can be illustrated with the presentation of the Veberian version SE.

\section{Veberian SE}

Some time ago I wrote the following about Veber's personalism and externalism:

"Yet all this is not enough to classify Veber as a relational personalist. Veber namely also love relationship still considers in the frame of paradigm experience-object, in the horizon of which it is also the relationship towards a person understood in the object and not in the dialogic way. In Veber's philosophy we cannot trace something like Buber's Zwischen. Such essential moments of love and dialogue remained hidden to Veber's thought. (...) Somebody might not completely agree with the above thesis. This disagreement can be grounded on Veber's distinguishing between presenting and hitting upon which he developed in his book Vprašanje stvarnosti (1939). Presenting, directedness to phenomena or objects is only one side of an experience and it is not fundamental. On the virtue of this late Veber's philosophy Matjaž Potrč (1989) classified Veber as an externalist, i.e. among philosophers claiming that we cannot understand or explain organisms' or persons' mental states or experiences without taking into account the aspects of the organisms' or persons' environment, as well physical as social. The environment of a person is formed also by other persons. Hence ascribing of externalist position to Veber might serve as a basis for ascribing him the relational personalism. Yet it is questionable whether we may truly talk about Veber as an externalist and whether a certain externalism is really sufficient for ascribing of the relational personalism. Let me add at this point that the approach which Veber cultivated in his social philosophy is a kind of methodological individualism. Further it is very questionable whether the externalist position is compatible with the acceptance of God as a creator of the world. Namely according to externalism, thought is logically dependent on the existence of the external world. Hence also God's thought is not possible before the existence of the world. (Howell, 2011) If externalism is not compatible with the Christian theism and if Veber is an externalist then his position would be inconsistent at least if we justifiably assume that in the time of the publication of the book Vprašanje stvarnosti Veber was accepting the existence of Christian God." (Žalec 2012, 39)

The following text further deals with the problem mentioned in the quote above. The thesis that Veber was a semantic externalist is difficult to prove because there is no adequate (textual) evidence which would prove that Veber thought that two persons/organisms can be in a completely identical narrow states (the same intension), but nevertheless in different semantic states (the reference or extension of their states is different). But on the basis of Veber's philosophy we can formulate a special version of semantic externalism which will be presented below. ${ }^{6}$ For a Veberian semantic externalist, the reference

Veber's thought in his book Vprašanje stvarnosti (Question of Reality), where he accepts the difference which could be roughly defined as a difference between primary and secondary qualities, also speaks in favor of this. Primary qualities are discovered by scien- 
of experience is not determined by the stereotypes of the person who experiences, but by a special causal relation of this person to each thing in the world. Veber calls this relation "hitting upon reality". We hit upon individual substances, but we present their characteristics or attributes. Peter ${ }_{1}$ in the world ${ }_{1}$ hits upon x-es which have the following attributes: substantiality, colorlessness (transparency), they are liquid, without odor etc. It turns out that those $\mathrm{x}$-es have the chemical structure $\mathrm{H}_{2} \mathrm{O}$. Experts say that the word 'water' refers to $\mathrm{x}$-es with the chemical structure $\mathrm{H}_{2} \mathrm{O}$.

God could not have created the world completely ex nihilo, otherwise he could not have had the thought about the world. But God had hit upon the world - therefore he had had the thought about it - and afterwards he equipped the world with attributes. ${ }^{7}$

We can have a thought about one thing if we hit upon it even if we do not know (all or any) of its attributes ${ }^{8}$ (but usually when we hit upon a thing we also present some of its attributes). Thus we can hit upon water (the thing with the chemical structure $\mathrm{H}_{2} \mathrm{O}$ ) without knowing that it is water (that it is the thing with the chemical structure $\left.\mathrm{H}_{2} \mathrm{O}\right)$. But if we hit upon water $\left(=\mathrm{H}_{2} \mathrm{O}\right)$ then our thought is about water (our thought refers to water) regardless of what we think about it (what attributes we ascribe to the entity upon which we hit).

The reference of a term is determined by its use for a particular thing we hit upon. Afterwards, experts decide what is the correct intension which we connect with the term, and we correct or supplement our intensions on the basis of the participation of experts' opinion. But intensions can also be corrected by experts themselves on the basis of new discoveries etc. Therefore, the term 'water' of Peter ${ }_{1}$ refers to $\mathrm{H}_{2} \mathrm{O}$ because his reference is determined by the hitting upon the things whose chemical structure is $\mathrm{H}_{2} \mathrm{O}$; and the term of Peter $_{2}$ refers to XYZ (because he hits upon the things which appear the same as those things upon which Peter ${ }_{1}$ hits, but their chemical structure is XYZ), although their intensions are the same. Therefore, (from Burge's example) Peter ' 's arthritis refers only to rheumatic inflammation of joints, and Peter 2 's to all rheumatic inflammations. Therefore, Peter $_{2}$ is right to correct his intension of the term 'arthritis'.

It is not necessary to have intensions first and only to refer afterwards: referring is possible, according to Veber, without intensions (pure hitting upon). It is our hitting upon which is fundamental since hitting upon determines the reference of our terms. Therefore, our intensions (concepts, definitions) can be false (or they need to be changed), otherwise it would be pointless to claim that our terms or definitions are not right or need to be supplemented. It can occur that the $\mathrm{x}$ to which we refer with a certain term (which has certain intension) actually does not have certain attributes which we thought that it had, or that it has some attributes we did not know about. Because of a social chain through which we "inherit" the reference of our terms it could seem that sense determines reference, but that is not true.

$$
\begin{aligned}
\text { Veber } & : \text { Putnam } \\
\text { hitting upon } & =\text { referring } \\
\text { presentations } & =\text { intensions }
\end{aligned}
$$

Taking into consideration that it was not a creation ex nihilo, but a creation from stuff, Veber's version of semantic externalism is compatible with the thesis that God intentionally (after his previous image) created the world. 
The world as stuff had existed, otherwise God could not have referred to it. Attributes (shapes, structures) had also existed. God's creation consists of his "equipping" the world with attributes (shapes, structures). That is a combinatory operation which semantic externalism allows.

\section{The radical difference of God, personalism, SE, and Veber}

The claim about too radical a difference between human beings and God is inacceptable for Christian personalism, since human beings are created in the image of $\mathrm{God}^{9}$ and therefore both human beings and God are persons. In some Veber's works (for example 1930, 1934, 1938, 1939, 1979) we can find reasons to claim that Veber, who used the terms 'person' and 'Person' (1930), was in a sense a Christian personalist and a theistic creationist. If Veber is a Christian personalist, ${ }^{10}$ it is not possible to avoid the tip of Howell's argument by referring to the radical difference between God and man, that it is not possible to apply the arguments of SE to God. But it should be said that Veber (in a certain period) defended a position which is not in accordance with Christian personalism. We shall dedicate the next part of this article to this position (and to its (in)consistency with Christian personalism and the rest of Veber's opus).

In the following two sections I will argue in favor of the thesis that Veber's personalism (as any other personalism) is incompatible with too radical a difference between human beings and God. Yet even within his philosophy we can find - in particular places - some claims that can serve as a foothold for such a claim of radical difference. In the following sections I will show which thesis is such a foothold. However, this thesis later disappeared from Veber's opus. On the other hand, Veber remained a personalist and he even developed, enriched, and elaborated his personalist position. Thus we can conclude that this tension with personalism (and the possibility of avoiding the application of SE to God) was a temporary phenomenon in his development rather than some central or essential part of his philosophy.

\section{1. (Veber's) personalism and the persons who are inherently bad/vicious}

After 1925, Veber took the direction of personalism and (with it) Christian philosophy (cf. Žalec 2002), but he did not develop in the hermeneutic direction. Yet $I$ think that the right way is a connection of both personalism and hermeneutics (cf. Žalec 2012). Veber thinks that things are worthy or unworthy as much as they are pleasant or unpleasant, beautiful or ugly. Their

ce (Putnam says that science discovers "the hidden" structure of things to which we refer with our terms, e.g. the chemical structure of water).

7

A similar idea we can find already in Plato's Timaeus.

8

Veber accepts the possibility of pure hitting upon reality, i.e. hitting which is accompanied by no presentation. In fact, he claims that at the beginning of the life of a person there is pure hitting upon and then gradually - in the course of life and development - the richness of presentation increases. At the end of life, the richness of presentation again decreases and we approximate again the point of pure hitting upon (Cf. Veber 1939).

9

Human being is not only an image of an image as same part of the Christian traditions taught (St. Augustine was opposed to this opinion; cf. Louth 1981).

10

Regarding Veber's personalism (regardless of the question of SE) see Žalec 2002 and 2012. For the topic Veber, person, and object theory compare Juhant 2005, 85-87. 
positive or negative value is determined by the value which is based on them, but it is not an inherent part of them or their constituent. Thus, for instance, a melody is the same whether it is beautiful or not (Žalec 2002, 22). Only persons are inherently worthy or unworthy (ibid.). Veber, in his book Filozofija (1930), defends the thesis that a person cannot influence whether she is good or vicious/bad. How could she change her essence? At this point Veber also mentions St. Augustine and his view about our determination for salvation/ damnation. Moreover, education (upbringing) cannot help a lot in this situation. It can help only to the extent that goodness is shown and that viciousness remains hidden, that a vicious person at least seems to be good (cf. Žalec 2002, 23). The good deeds are her merit and the bad deeds are her guilt. ${ }^{11}$

Personal evaluation may be reactive or reflective. If it is reactive then it results in love or hate; if it is reflective then it is respect or disrespect. But there is another difference between love and hate at one hand and respect and disdain on the other: love and hate show us goodness and viciousness from our own position, but respect and disdain show us "at the same time in the light of general duty" (Veber 1930/2000). ${ }^{12}$

Veber's position about person's inherent goodness/viciousness is of extreme importance for the determination of his personalism. This claim is in a certain sense unacceptable for personalism because it allows that we hate certain person as such. In my opinion this claim is also incompatible with Christianity. Jesus commanded that we must love every person, including our enemies. Following Veber's thought (from Filozofija /1930/) it is impossible to meet this command because some persons are inherently vicious and therefore we cannot love them if we feel correctly. Moreover, it is just the opposite that is true: if we feel correctly, we should hate them because love is an emotion directed towards goodness and hate an emotion directed towards viciousness.

Veber's position from Filozofija is incompatible with Christian personalism since for personalism every person holds the highest value. The position that some persons are inherently vicious can serve as a basis for things like death penalty. If a person's viciousness is inseparable from the personality (and she also committed some very vicious deeds), what hinders us to execute her? The basis of the incompatibility of Christianity and the (Veber's) inherence thesis is the Christian position that every man is in his essence an image of God. God is the absolute goodness. How can any man then be inherently vicious? ${ }^{13}$

For Christianity and Christian personalism it is very important to distinguish between a person, on one hand, and her weaknesses (or vices) and deeds on the other. Person as such is always something good because she is God's image. We must think about people in the spirit of love towards man and hate towards his imperfections, weaknesses, vices, and sins. As St. Augustine wrote:

"Et hoc quod dixi de oculo non figendo, etiam in caeteris inveniendis, prohibiendis, indicandis, convincendis, vindicandisque peccatis diligenter observetur, cum dilectione hominum et odio vitiorum." (Epistola 211, 11) 14

The thesis about inherent viciousness of some persons is not in accordance with this attitude. To some extent, such non-personalist attitude can be hindered or inhibited by the epistemological argument that our personal emotional experiences can be incorrect. But, taking into consideration Veber's teleological argumentation (which is also presented in Filozofija), this reason loses its weight since from Veber's teleological argumentation it follows that our emotions are mostly correct, at least when virtuous persons are in question. 
But, on the other hand, there are some facts in favour of Veber's thesis. One of them is that to love means to love despite vices or immoral characteristics and deeds of the beloved person. But what about hate? Does to hate also mean to hate despite the moral characteristics or deeds of the hated person? Is not the hypothesis that some people are (more) successful in reaching the core which is their goodness, and thus we love them, and that some other are not successful in doing so (and often that is understandable, e.g. with severe criminals) more acceptable?

\subsection{The (in)coherence of the inherence thesis within the rest of Veber's opus}

Besides the already mentioned problems regarding Veber's inherence thesis, there are also the ones which consider its coherence within the rest of Veber's philosophy. Veber, in his book Nacionalizem in krščanstvo (1938), claims that love is a necessary basis for justice. Can we be just to people who we consider to be inherently vicious? What does it (not) pertain to people who are inherently vicious? There also arises the question about the compatibility of Veber's thesis about some persons being inherently vicious with his (later) claims and positions, e.g. with his humanistic anthropocentric theocentrism, which considers the human being as, in the words of Tommaso Campanella, "dio secondo, miracolo del Primo".

Veber claims, in his book Znanost in vera (1923), that the confessional beliefs of believers are not knowledge since they are heteronomous and not autonomous. They are a type of moral experiences, Veber claimed in Znanost in vera (cf. also Žalec 2002, 24). A believer presents moral values as founded upon certain facts - for example that Jesus made wine out of water - and experiences genuine moral emotions. The main criterion of every confession is, according to Veber, its bigger or lesser emotional and intellectual accordance with the ethical and moral sense of humanity (cf. Žalec 2002, 24). At this point, some basic and crucial questions arise. How does Veber's thesis about the inherent viciousness of some persons correspond to the ethical and moral sense of humanity? Which ethical sense tells us that some persons are inherently morally vicious? What can we say about Christianity (Jesus' "doctrine") in the light of the ethical and moral sense which tells us that some persons are inherently vicious? First and foremost: what does Veber have in mind when he speaks about the ethical and moral sense of humanity? The inherence thesis is hardly compatible with the so-called World Ethos (Hans Küng) since the holiness of life is one of the core principles of the World Ethos. The best candidate to explain what Veber thought with the term 'ethical and moral

11

This Veber's thought is in accordance with the view about the power of will which is a result of modern research show that its power is mostly hindering.

12

See also Žalec 2002, 22.

13

It is interesting to see that the questionableness (from Christian perspective) of Veber's thesis (from Filozofija) about the inherent viciousness of some persons is neither mentioned nor questioned by any of the numerous critics and reviewers of Veber's work ( $F i$ lozofija), among them also members of the Slovene Christian intellectual and philosophical elite. About the exceptional reception of Veber's Filozofija see Žalec 2000.

14

"What I have now said in regard to abstaining from wanton looks should be carefully observed, with due love for the persons and hatred of the sin, in observing, forbidding, reporting, proving, and punishing of all other faults." See also Regula ad servos Dei, 4, 28. 
sense', which he used in his book Znanost in vera (1923), is, in my opinion, conscience. ${ }^{15}$ If the ethical and moral sense of humanity is conscience then Veber's thesis about the inherent viciousness of some persons becomes very problematic from the point of view of this moral sense (i.e. conscience) since many people who reject death penalty accept the values or principles of the World Ethos, emphasize the importance of respecting conscience etc. They do not accept the thesis about the inherent viciousness of some persons. I belong to them. Therefore, the thesis about the inherent viciousness of some persons cannot be based on conscience or a kind of genuine ethical and moral sense of humanity. And if there is a kind of real ethical and moral sense of humanity (conscience) which is a measure for the acceptability of Christianity or real Christianity, then the thesis about the inherent viciousness cannot be based on (genuine) Christianity.

\section{Conclusion}

We can conclude that the inherence thesis is not compatible with Christianity and Christian personalism. Maybe that is the reason why we do not find this thesis in Veber's opus either before or after Filozofija (1930). Veber was in a position where he had to decide between the inherence thesis and Christianity with Christian personalism. It seems that he chose the second option.

The acceptance of personalism pushes Veber's philosophy even more towards the general acceptance of SE since it makes the rejection of the application of $\mathrm{SE}$ arguments in the context of God even less convincing. So we can see that personalism and SE are (maybe surprisingly) connected: accepting personalism is in favour of the generality of SE (it is also valid in the case of God) and therefore personalism is attractive to SE at least as far as a semantic externalist is attracted by the greater generality of his thesis. On the other hand, accepting SE may be attractive for a personalist since accepting SE (which by "its nature" includes the attractiveness of its generality) implies the inclination towards the affirmation of the essential similarity between a human being and God, and between a person and the Person, implying personalism. Awe towards God based on the difference between God and human beings, which is stressed by some apophatic theologians, is not endangered by the genuine Christian personalistic attitude since any human being is a person precisely because only human beings are similar to Somebody who is radically different from all creations.

Howell (2011) points out that SE has become a kind of dogma of naturalistic atheists (who, of course, also reject creationist theism), and if Howell's argument about the incompatibility of CT and SE was valid, then we could say that the inclination of naturalist atheists toward SE makes sense. But I think that it is not so. We can prevent creationist theism being endangered by SE in different ways. One which first comes to mind is a thesis about the radical difference of God in comparison with man. But if we exaggerate this thesis we endanger the view that talking about human's similarity with God makes sense (and with this the justification of Christian personalism). The second possibility is to accept SE and maintain CT in a Timaeusian version.

Howell claims that SE and CT - even in the variant of stuff creationism - are incompatible because he does not take into account the differences between hitting upon reality and presentation (reference and intension, Bedeutung and Sinn). Veber's theory of hitting upon reality adds an important enlightening 
component to the more accurate semantic, phenomenological, and ontological picture of the mind-world relation or structure. ${ }^{16}$

\section{References}

Aurelius Augustinus. S. Aurelii Augustini opera omnia: patrologiae latinae elenchus. Available at: http://www.augustinus.it/latino/ (accessed on July 24, 2015).

Burge, T. (1979). "Individualism and the Mental". In: Midwest Studies in Philosophy 4 (1/1979), pp. 73-122. doi: https://doi.org/10.1111/j.1475-4975.1979.tb00374.x. [also Ch. 5 in Burge 2007]

Burge, T. (2007). Foundations of Mind: Philosophical Essays, Vol. 2. [Kindle Edition]

Burge, T. (1989). "Individuation and Causation in Psychology". In: Pacific Philosophical Quarterly 70, pp. 303-322. [also Ch. 14 in Burge 2007]

Burge, T. (1986a). "Cartesian Error and the Objectivity of Perception”. In: Pettit, P., McDowell, J. (eds.), Subject, Thought and Context, pp. 107-119. Oxford: Oxford University Press.

Burge, T. (1986b). "Individualism and Psychology". In: The Philosophical Review 95 (1/1986), pp. 3-45. doi: https://doi.org/10.2307/2185131. [also Ch. 9 in Burge 2007]

Davidson, D. (1990). "The Structure and Content of Truth". In: The Journal of Philosophy 87 (6/1990), pp. 279-328. doi: https://doi.org/10.2307/2026863.

Dretske, F. (1995). Naturalizing the Mind. Cambridge (MA) - London: A Brandford Book - The MIT Press.

Fodor, J. A. (1994). The Elm and the Expert: Mentalese and Its Semantics. Cambridge (MA) - London: The MIT Press.

Fodor, J. A. (1991a). “A Modal Argument for Narrow Content". In: Journal of Philosophy 88 (1/1991), pp. 5-26. doi: https://doi.org/10.2307/2027084.

Fodor, J. A. (1991b). A Theory of Content and Other Essays. Cambridge: The MIT Press.

Howell, R. (2011). "The Skeptic, the Content Externalist, and the Theist". In: International Journal for Philosophy of Religion 69 (3/2011), pp. 173-180. doi: https://doi.org/10.1007/ s11153-010-9261-6.

Juhant, J. (2005). "Veber's Ethik in dem 'System der Wissenschaft"”. In: Anthropos 1-4, pp. 81-94.

Lafont, C. (2005). “Was Heidegger an Externalist?”. In: Inquiry 48 (6/2005), pp. 507-532. doi: https://doi.org/10.1080/00201740500320054.

Louth, A. (1981). The Origins of the Christian Mystical Tradition. From Plato to Denys. Oxford: Clarendon Press.

Marr, D. (1982). Vision. San Francisco: W. H. Freeman and Company.

Pihlar, T. (2011). "From Descriptive to Dynamic Psychology". In: Pirc, T. (ed.), Object, Person and Reality: An Introduction to France Veber, pp. 107-119. Ljubljana: Javni sklad Republike Slovenije za kulturne dejavnosti.

15

In the same year as Znanost in vera, Veber also published his Etika, which deals with the ethics of conscience (cf. Žalec 2002; Strahovnik 2012). At the end of his article, Strahovnik presents the concept of conscience in Veber's Etika and defines its epistemic role.

16

I presented the short version of this essay at a conference in Dublin, which took place in
March 2012 and was devoted to the work of Professor Santiago Sia. I would like to thank Professor Sia for the invitation to the conference and for all hospitality in Dublin. I would also like to thank all the participants of the conference who commented on my paper. However, my main thanks goes to my colleague from Ljubljana, Vojko Strahovnik, for his suggestions and comments regarding this essay. 
Pirc, T. (ed.) (2011). Object, Person and Reality: An Introduction to France Veber. Ljubljana: Javni sklad Republike Slovenije za kulturne dejavnosti.

Plato (1997). “Timaeus”. In: Cooper, J. M. (ed.), Plato. Complete Works, pp. 1224-1292. Indianapolis - Cambridge (MA): Hackett Publishing Company.

Potrč, M. (1989). “Veber's Externalism and Internalism”. In: Acta Analytica 4, pp. 51-64.

Putnam, H. (1992). “A Theory of Reference”. In: Putnam, H., Renewing Philosophy, pp. 35-59. Cambridge (MA) - London: Harvard University Press.

Putnam, H. (1991a; $\left.{ }^{1} 1981\right)$. "Brains in a Vat". In: Putnam, H., Reason, Truth and History, pp. 1-21. Cambridge et al.: Cambridge University Press.

Putnam, H. (1991b; $\left.{ }^{1} 1981\right)$. "A Problem about Reference”. In: Putnam, H., Reason, Truth and History, pp. 22-48. Cambridge et al.: Cambridge University Press.

Putnam, H. (1991c; $\left.{ }^{1} 1981\right)$. “Two Philosophical Perspectives”. In: Putnam, H., Reason, Truth and History, pp. 49-74. Cambridge et al.: Cambridge University Press.

Putnam, H. (1991d): Reason, Truth and History. Cambridge et al.: Cambridge University Press.

Putnam, H. (1987). The Many Faces of Realism. LaSalle (IL): Open Court.

Putnam, H. (1975). "The Meaning of 'Meaning'”. In: Putnam, H., Mind, Language and Reality. Philosophical Papers, Volume 2, pp. 215-271. Cambridge: Cambridge University Press.

Strahovnik, V. (2012). "France Veber and His Ethics of Conscience". In: Pirc, T. (ed.), Object, Person and Reality: An Introduction to France Veber, pp. 131-146. Ljubljana: Javni sklad Republike Slovenije za kulturne dejavnosti.

Veber, F. (22000). Filozofija. Načelni nauk o človeku in njegovem mestu v stvarstvu [Philosophy: A Principled Doctrine about Man and His Place in Creation]. Ljubljana: Študentska založba.

Veber, F. (1979). Zadružna misel. Izbor člankov in razprav [Cooperative Thought: Selected Essays]. Buenos Aires: Cooperativa de Credito, S.L.O.G.A. LTDA.

Veber, F. (1939). Vprašanje stvarnosti. Dejstva in analize [Question of Reality: Facts and Analysis]. Ljubljana: Akademija znanosti in umetnosti v Ljubljani.

Veber, F. (1938). Nacionalizem in krščanstvo. Kulturna pisma Slovencem [Nationalism and Christianity: Cultural Letters to Slovenians]. Ljubljana: Ivo Peršuh.

Veber, F. (1934). Knjiga o Bogu [The Book on God]. Celje: Mohorjeva družba.

Veber, F. (1930). Filozofija: načelni nauk o človeku in njegovem mestu v stvarstvu [Philosophy: A Principled Doctrine about Man and His Place in Creation]. Ljubljana: Jugoslovanska knjigarna.

Veber, F. (1923b). Etika. Prvi poizkus eksaktne logike nagonske pameti [Ethics: A First Attempt of an Exact Logic of Instinctive Reason]. Ljubljana: Učiteljska tiskarna.

Veber, F. (1923a). Znanost in vera. Vedoslovna študija [Science and Faith: Epistemological Study]. Ljubljana: Tiskovna zadruga.

Veber, F. (1921). Sistem filozofije. Prva knjiga. O bistvu predmeta [System of Philosophy. Volume One. On the Essence of Object]. Ljubljana: Ig. Pl. Kleinmayr in Fed. Bamberg.

Žalec, B. (1999). Realizem in reprezentacijska teorija duha [Realism and Representational Theory of Mind], PhD thesis. Department of Philosophy, Faculty of Arts, University of Ljubljana. Ljubljana: University of Ljubljana.

Žalec, B. (2000). "Slovenska filozofska mavrica leta 1930" [Slovene Philosophical Rainbow in 1930]. In: Veber, F., Filozofija. Načelni nauk o človeku in njegovem mestu v stvarstvu [Philosophy: A Principled Doctrine about Man and His Place in Creation], pp. 245-321. Ljubljana: Študentska založba. 
Žalec, B. (2002). Spisi o Vebru [Essays on Veber]. Ljubljana: Študentska založba.

Žalec, B. (2012). “An Integral Survey and Evaluation of Veber's Philosophy in the Light of Hermeneutics and Personalism". Pirc, T. (ed.), Object, Person and Reality: An Introduction to France Veber, pp. 29-49. Ljubljana: Javni sklad Republike Slovenije za kulturne dejavnosti.

\title{
Bojan Žalec \\ Zašto se semantički eksternalizam, kreacionistički teizam, personalizam i Veberova filozofija vrlo dobro slažu
}

\begin{abstract}
Sažetak
Glavne su teze ovoga rada: 1. semantički eksternalizam (SE) i kreacionistički teizam (CT) su kompatibilni; 2. SE i personalizam su međusobno nakloni. Ovaj se stav može plodonosno ilustrirati $i$ obogatiti upotrebom filozofije Francea Vebera (1890.-1975.). Veber je bio Meinongov učenik. Smatrao je da postoji poseban aspekt našeg iskustva koji je nazvao 'nailaženje na stvarnost' $i$ koji je fundamentalno drukčiji od prezentacije fenomena. Autor ukazuje na neke paralele distinkcije između nailaženja na stvarnost i prezentacije s jedne strane te Putnamova stava o referenciji i reprezentaciji s druge. Najvažnije sastavnice referentnog okvira ovoga rada djela su filozofa Roberta Howella, Hilarya Putnama, Tylera Burgea i Francea Vebera. Temeljni izvorni doprinos ovog rada predstavlja zaključak da su SE i personalizam međusobno nakloni.
\end{abstract}

Ključne riječi

semantički eksternalizam, kreacionistički teizam, personalizam, nailaženje na stvarnost, Robert Howell, France Veber

\section{Bojan Žalec}

\section{Warum der semantische Externalismus, Personalismus und Vebers Philosophie sehr gut zusammenpassen}

\section{Zusammenfassung}

Die Hauptthesen des vorgestellten Artikels sind: 1. Der semantische Externalismus (SE) und der kreationistische Theismus (CT) sind kompatibel; 2. Der SE und der Personalismus sind zueinander geneigt. Diese Ansicht kann durch die Verwendung der Philosophie France Vebers (1890-1975) fruchtbringend dargestellt und angereichert werden. Veber war Meinongs Schüler. Er argumentierte, es bestehe eine spezielle Seite unserer Erfahrung, die er ,,Treffen der Wirklichkeit" nannte, und die sich von der Darstellung der Phänomene grundlegend unterscheidet. Der Autor weist hin auf einige Parallelen der Distinktion zwischen dem Treffen der Wirklichkeit und der Präsentation einerseits und Putnams Standpunkt zur Referenz und Repräsentation andererseits. Die bedeutendsten Konstituenten des Referenzrahmens für dieses Paper sind die Werke von Philosophen wie Robert Howell, Hilary Putnam, Tyler Burge und France Veber. Der originelle Hauptbeitrag dieses Artikels repräsentiert die Feststellung, der SE und der Personalismus seien zueinander geneigt.

\section{Schlüsselwörter}

semantischer Externalismus, kreationistischer Theismus, Personalismus, Treffen der Wirklichkeit, Robert Howell, France Veber 


\title{
Bojan Žalec
}

\section{Sur la question de savoir pourquoi l'externalisme sémantique, le théisme créationniste et la philosophie de Veber s'articulent harmonieusement les uns avec les autres}

\begin{abstract}
Résumé
Les principales thèses de cet article sont les suivantes : 1. L'externalisme sémantique (SE) et le théisme créationniste (CT) sont compatibles ; 2. SE et le personnalisme tendent réciproquement l'un vers l'autre.

Ce point de vue peut être avantageusement illustré et enrichi en s'appuyant sur la philosophie de France Veber (1890-1975). Veber a été l'élève de Meinong. Il affirmait que notre expérience avait un côté particulier qu'il appelait hitting-upon-reality et qui est fondamentalement différent de la présentation d'un phénomène. D'une part notre auteur tire des parallèles sur la distinction entre le concept de hitting-upon-reality et de présentation, et d'autre part il met en parallèle le point de vue de Putnam sur la référence et sur la représentation. Les principales composantes du cadre de référence pour cet article reposent sur les travaux des philosophes Robert Howell, Hilary Putnam, Tyler Burge and France Veber. Sa principale contribution consiste en la démonstration que l'externalisme sémantique et le personnalisme tendent réciproquement l'un vers l'autre.
\end{abstract}

\section{Mots-clés}

externalisme sémantique, théisme créationniste, personnalisme, hitting-upon-reality, Robert Howell, France Veber 